\title{
Teaching tourism: urban routes design using GIS Story Map
}

\author{
La enseñanza del turismo: \\ diseño de rutas urbanas usando los GIS Story Maps
}

\author{
Carmen Mínguez ${ }^{1}$ (1)
}

\begin{abstract}
The different degrees on Tourism seek to train experts capable of managing changes and stimulating the necessary improvements to be able to maintain and enhance the dynamic tourism sector. This paper provides the design of a teaching activity for students of tourism degree. With it, it is intended that students, through collaborative work methodology and through the use of geospatial technologies, especially the GIS Story Map, acquire essential competencies in their training and are capable of creating a tourist product according to the characteristics of the destination. The didactic experience consists of creating an original and innovative tourist route in Madrid. This way, a collaborative map and a series of individually presented routes are obtained that are co-evaluated by the students themselves. The results of a satisfaction survey about the activity answered by the participants are also presented. It appears that the activity has been considered positive, since the students claim to have acquired skills of great interest in their training as future professionals, while feeling motivated. We conclude by pointing out that it is necessary to include this type of initiative in university education and that this methodology can be extrapolated to other subjects and places.
\end{abstract}

Keywords: Story mapping; collaborative work methodology; geospatial technologies; urban routes; tourism training; professional competences; Madrid.

\section{Resumen}

Los Grados en Turismo buscan formar expertos capaces de gestionar cambios e impulsar las mejoras necesarias que permitan mantener, potenciar el dinámico sector turístico. Este artículo propone el diseño de una actividad docente para estudiantes del Grado en Turismo. Con ella se pretende que los estudiantes, a través de una metodología de trabajo colaborativo y mediante el uso de las geotecnologías, especialmente de los GIS Story Map, adquieran habilidades esenciales en su formación y sean capaces de crear un producto turístico acorde a las características del destino. La experiencia didáctica consiste en crear una ruta turística original e innovadora en Madrid. Se obtiene así un mapa colaborativo y una serie de rutas presentadas de manera individual que son coevaluadas por los propios estudiantes. También se presentan los resultados de una encuesta de satisfacción con la actividad respondida por los participantes. Se desprende que la actividad es positiva, ya que los estudiantes afirman adquirir habilidades de gran interés en su formación como futuros profesionales, al tiempo que se sienten motivados. Concluimos señalando que es necesario incluir este tipo de iniciativas en la enseñanza universitaria y que esta metodología es extrapolable a otras materias y lugares.

1 Department of Geography, Faculty of Geography \& History, Complutense University of Madrid, 28040 Madrid, Spain. cminguez@ghis.ucm.es 
Palabras clave: Story Map; metodología de trabajo colaborativo; geotecnologías; rutas urbanas; enseñanza del turismo; competencias profesionales; Madrid.

\section{Introduction}

Tourist activity is exposed to constant changes and generates significant impacts on the environment. Its professionals have to adapt to this situation, they need to prepare to act, to think and plan differently (Sheldon, Fesenmaier, Woeber, Cooper \& Antonioli, 2008). Tourism training must include different pedagogical approaches that train its students and promote the development of skills and aptitudes, while reinforcing their training in values (Veugelers, 2000). This is the only way of allowing current students to become the type of professionals who will be capable of adapting to a very dynamic, fragile and extremely vulnerable sector in the future, as has been recently shown by the COVID-19 crisis, as well as looking for strategies that favour responsible consumption in the Anthropocene epoch.

This article has the objective of designing a collaborative work methodology with the student centred learning which consists of: (1) the creation of a tourist product, (2) its presentation through a Story Map², (3) the generation of information through feedback among students and (4) the co-evaluation of the final tourist product. To do this, students are asked to design tourist routes for the city of Madrid covering all phases of the development process (planning, development, promoting and evaluation). This destination was chosen because it is the city where they study and because, at the beginning of the year 2020, it has very well defined tourist characteristics that must be taken into consideration in order to achieve this proposal. At that time Madrid was defined by a situation of clear overtourism, concentration of tourists in very specific places and a context of high competitiveness (Calle, Ferreiro \& Mendoza, 2018; Milano, 2018). This way, students become active subjects of their own work (Shor, 2012) and learning becomes experiential (Kolb, Boyatzis \& Mainemelis, 2001), with the advantages that it entails. Therefore, the students should be able to acquire certain skills such as: creativity, teamwork, capacity for planning and organising, narrative y spatial and digital competencies, through different strategies such as self-learning and co-evaluation; as well as a range of tools, among which the geospatial technologies are especially worth noting.

This document describes the process and the results of a didactic experience in the classroom based on authentic student learning in the Tourism Degree. Different techniques have been used to achieve this purpose within the framework of an active methodology, which affect both the project design and the development process itself, as well as its evaluation. The text is structured in six points. After this short introduction, the first point of the article presents a review of the literature on two main themes: the pedagogical principles that serve as the basis of this initiative and, more specifically, the Story Maps and tourism products, especially the routes, which give the keys to the most important aspects that have been considered for the design of the activity. Next, both the methodology used and the different techniques and tools that have been applied in each phase of the activity will be offered, to continue later on with the presentation of the results and their critical analysis. Finally, the article will conclude summarising the conclusions in detail.

\subsection{Theoretical framework}

\subsubsection{GIS Story Map as a teaching tool}

There has been a revolution in geographic information during the last two decades that has resulted in a significant proliferation of Geographic Information Technologies (GIT). Many of them, although they have been designed for domestic use, such as GPS, or even business or institutional use such as ArcGIS Online, are also used in teaching. The GITs have marked an important transformation in teaching (De Miguel \& De Lázaro, 2020), especially at Secondary level, being fundamental tools at schools where pedagogical principles based on active methodologies such as project learning, student centred learning or personalized teaching prevail over other methods (Martínez-Hernández, 2014; Martínez-Hernández, Ibarra, Pérez \& Figueres, 2016; De Lázaro, De Miguel \& Morales, 2017).

These tools - known as geospatial technologies - foment the acquisition of spatial knowledge and skills based on localisation, which involve three points of great relevance: spatial concept, spatial

2 Esri tool based on its Cloud ArchGIS Online platform. 
representation and spatial reasoning (Michel \& Hof, 2013). The spatial knowledge implies a geographical literacy necessary for understanding the environment and consequently the daily development of current life and decision-making (Patterson, 2007; Buzo, De Lázaro \& Mínguez, 2014; Dangermond, 2016). Such is its relevance that in 2016 the Geographical Education Commission (IGU-CGE) presented the International Charter on Geographical Education, which recognises its interest in the development of today's society and therefore its incorporation into teaching at the Primary and Secondary levels (Stoltman $\&$ Lidstone, 2017). Among the most used tools are viewers, virtual globes, SIGWebs, interactive atlases, GPS or GIS Story Maps (GSM). The latter are a storytelling technique and are essential in the construction of stories, accompanied by interactive maps and graphic contributions (Strachan \& Mitchell, 2014; De Lázaro, Borderías \& Morales, 2020). These are more and more frequent for the creation of personalised, collaborative and even interactive atlases, such as those presented by Strachan \& Mitchell (2014), De Miguel, Buzo \& De Lázaro (2016) or Berendsen, Hamerlinck \& Webster (2018), among others.

The maps, the texts and all the graphic support that can be included allow working both narrative and cartographic skills, linked not only to their preparation, but also to their interpretation and critical analysis (Dickinson \& Telford, 2020). Therefore, the atlases created with GSM have a dual function in teaching: on one hand, they are used like traditional atlases, since they are a compendium of information represented essentially with maps that allow the interpretation of a spatial phenomenon and, on the other hand, they are a didactic tool in and of itself, which allows the elaboration and updating of thematic cartography and the preparation of the dissertation (Marta \& Osso, 2015; Berendsen, et al., 2018).

The creation of a GSM presents a series of advantages for education such as (Kerski, 2019): fostering technical skills and oral communication, allowing an attractive and visual presentation of the results of the work and encouraging discussion with their peers. Also, they have a significant degree of autonomy and promote self-learning; therefore they have been implemented in non-formal education projects. In addition to this, the GSM entail a series of elements that are of interest to teachers (Esri, 2012): A Story or message to communicate; a text or guide to help the user interpret your maps; a Spatial data that supports the author's story, a Cartography, an attractive representation of spatial data, other visual elements to enhance the story (graphs, pictures, charts, videos, maps, etc.) and user experience that offer a certain design and functionality. Thanks to them, a series of transversal competencies highly valued by companies can be developed, such as: the ability to identify problems, creativity, leadership skills, use of the GITs and teamwork (García \& Pérez, 2008; Cárdenas-García, Pulido-Fernández \& Carrillo-Hidalgo, 2016; Rodríguez, Rubio, Esteban \& Alonso, 2019).

For all these reasons, the GSM are also useful at the university, where they are being used for the practical part of the subjects taught by geographers in different degrees. They know how to use geoinformation sources (González \& De Lázaro, 2011) and, through initiatives such as innovation projects, they have acquired knowledge in the use of the tools available in the web environment (Buzo, et al., 2014). In addition to this, they are conscious of the extra value that these tools possess, which are very important in the training of professionals since they favour empowerment and engage the stakeholders in planning (Nguyen, Edwards, Rahall, Scott \& Cragle, 2016). Despite all of this, the use of the GSM is still limited, as revealed by the scarce existing literature on the matter, but it does not prevent it from being very appealing and showing important applications for the Degree in Tourism to respond to current tourism challenges (Martínez-Hernández \& Yubero, 2020).

In this context, the use of tools such as geovisors, WebGIS and especially GIS is more and more common, which is fundamental in promoting knowledge and also in motivating students (Schott \& Sutherland, 2009). Additionally, these tools and especially the GIS are increasingly used in tourism research to analyse the spatial distribution of the phenomenon and its elements (resources, tourists, accommodation, travel routes, etc.) and consequently also in the classroom at different educational levels (Master or Degree). They are used to teach how to collect geographical information and create cartographies that illustrate reality and provide information that favours a better understanding for planning (Chen, 2007; Stankov, Durdev, Markovic \& Arsenovic, 2012).

Among the most common initiatives completed in the classroom with geospatial technologies are virtual routes or walks, made with Google Earth, Google Voyager, ArcGIS Online and its Story Maps and even with Virtual Reality tools. These are proposed with different objectives, such as confirming whether these types of initiatives favour real travel (Tussyadiah, Wang \& Jia, 2017) or facilitate travel planning (Gavalas \& Kenteris, 2011; Ilies \& Ilies, 2018). With these initiatives, the routes are given an important 
educational value not yet sufficiently exploited in Tourism studies. Its value resides in the fact that, due to their characteristics, they allow students to develop a large number of skills, such as space competencies, those related to creativity and teamwork, and also digital competencies, all of which pose a challenge for professionals in the tourism sector.

\subsubsection{Routes: from tourist product to didactic resource}

If there is something that characterises tourism during the last two decades, it is its dynamism and the need for constant reinvention by destinations in order to be attractive and competitive. Many of these destinations are creating their own icons based on localised resources that are converted into new products; often without taking into account the characteristics and problems of the place (Arnandis-i-Agramunt, 2019). All this effort is made to attract more tourists and generate greater economic benefits, since it is considered to be an important opportunity for business development and sometimes even for citizen participation.

A tourist product is defined as the "set of goods and services that are the object of acquisition, use or consumption by people who are in the context of a tourist trip" (Blanco, et al., in press). It is made up of various elements that are marketed together to meet the needs of travellers. This implies important challenges, despite which the products are considered essential in the creation and especially in the modernisation of the destinations; therefore, both the companies and the public administrations focus their efforts and budgets on their development, being an essential part of their strategy. Among the challenges that make the commercialisation of these products more difficult, the following ones stand out: 1 . the diversity and heterogeneity of the elements that compose them, which generates marketing problems and involves various agents and 2. The intangibility of these products, which means that they can only be valued when consumed, without being previously tested, and cannot be prepared in advance nor stored (Buhalis, 2000; Benur \& Bramwell, 2015; Blanco-Romero, et al., in press).

Their difficulty and above all their economic, social and territorial repercussion has possibly been the reason why the design and the improvement of touristic products have been studied since the beginning of the 21st century by numerous researchers. They have analysed in detail the process of transforming the resource into a product, with different approaches, essentially from a marketing and a geographic point of view (Smith, 1994; Buhalis, 2000; López, Lara de Vicente \& Merinero, 2006; Mossberg, 2007, among others). In all these studies, two essential ideas have emerged. First of all, tourist routes are one of the most frequently implemented and therefore studied products, which has even led to the publication of monographs and special issues of magazines such as Sustainability-2019 or Papers de Tourisme-2019, among others. And secondly, the characteristics of the routes and their relationship to traveling itself make them difficult to define since it is often associated with a list of resources to be visited without taking into consideration that the route is the destination itself (Torres, 2006). Also, in relation to the situation during the last decades, indicated in the first paragraph of this section, it needs to be taken into account that the routes have become powerful elements of differentiation between destinations since they have been used to publicise part of their heritage (tangible and intangible) and reinforce or reorient the image of the place itself. In addition to this, they have been used as a measure of decongestion, in contexts of overtourism, being essential in the regulation of the influx in closed spaces and the enhancement of new neighbourhoods, spaces that up until now were outside of the areas which were considered the touristic part of the cities. Consequently, the routes contribute to the response to those challenges that have characterised urban tourism until the beginning of 2020.

The proliferation of case studies and research in this area has motivated the design and analysis of routes to become one of the most frequent exercises in some subjects of the Degree in Tourism. This way, the route becomes a recurring didactic resource, especially for the specific degrees on tourist guiding. This can be oriented in two ways: the first and most frequent is as a didactic itinerary through a natural or urban environment consisting of directed field work in which the territory replaces the classroom and allows active practice and new work methodologies and the second, is the design of routes in the classroom, thanks to the use of the Internet that offers online cartography, viewers, platforms, etc. (Portillo, Merino y García-Rodríguez, 2017). In these cases, teachers usually establish a script with the main elements that a route must include, followed by the models already developed by the public administration or private companies, analysed with detail by the academic literature (Pulido, 2006; Navalón-García, 2014). 
Taking all this into consideration, the starting idea of this article is about the convenience of introducing GSM in university education in order to (1) create productions that reduce the intangibility of the tourist product to be sold, offering a kind of model to the stakeholders in charge of its sale and (2) lay a foundation for creating an alternative final product to the real visit, which can be developed in greater depth and completed with Virtual Reality and 3D. This is a way to generate virtual visits that, up until March 2020, has been considered as a way to encourage real visits and since then, with the global lockdown of citizens from the main producing countries of the world, they have started to contemplate these virtual visits as an alternative to traveling. Initially, these can be understood as entertainment but in the near future it may be key in the reorientation of global tourism.

With all this taken into account, it is established as hypothesis of this research that the teaching methodology based on the use of GSM improves the performance of students and allows their acquisition of skills that will be key in their professional future. Also, a series of questions are raised such as: Are GSM a suitable tool? What kinds of skills do they really provide? Are they easy to use and therefore are applicable as a teaching resource? Or even, to what extent can the results be offered as alternatives to real routes? And therefore, what place do they have in a possible change of the tourism model?

\subsection{Learning objectives for the course}

The subject "Itineraries and tourist information" is an elective class for the students of the last two years of the Degree in Tourism at Complutense University of Madrid (UCM, 2019a). It is structured in two well-differentiated parts: the objective of the first part is to develop the ability to analyse and design tourist itineraries and routes, for which the resources, of a marked territorial nature, will be valued as well as the agents involved in them. Likewise, they must know how to use the techniques and methodologies for their design and development. The objective of the second part of the subject is to develop communication strategies for tourist information, as a key for the enhancement of resources, while analysing the role that technologies play together with communication (UCM, 2019b).

Table 1. Learning objectives and competencies of the subject

\begin{tabular}{|c|c|c|}
\hline & Learning objectives & Competencies \\
\hline Related to the subject & $\begin{array}{l}\text { 1. Obtain theoretical knowledge about the different } \\
\text { types and approaches of markets and tourist } \\
\text { itineraries. } \\
\text { 2. Achieve the competencies to develop } \\
\text { instruments that contribute to knowing the } \\
\text { resources that may intervene or be valued in } \\
\text { tourist itineraries. } \\
\text { 3. Identify and manage tourist itineraries. } \\
\text { 4. Know how the itineraries affect the creation of } \\
\text { destinations. } \\
\text { 5. Analyse the impacts generated by the itineraries. } \\
\text { 6. Be able to critically manage methodologies to } \\
\text { communicate tourist information and to design } \\
\text { itineraries. }\end{array}$ & $\begin{array}{l}\text { 1. Work in an international context. } \\
\text { 2. Recognition of diversity and } \\
\text { multiculturalism. } \\
\text { 3. Knowledge of other cultures and } \\
\text { customs. } \\
\text { 4. Sensitivity towards environmental } \\
\text { issues. } \\
\text { 5. Critical thinking. } \\
\text { 6. Ethical commitment. }\end{array}$ \\
\hline $\begin{array}{l}\text { Directly related to the } \\
\text { activity }\end{array}$ & $\begin{array}{l}\text { 7. Design a tourist itinerary. } \\
\text { 8. Study profoundly the role of new technologies } \\
\text { at the service of tourist information. } \\
\text { 9. Develop techniques and methodologies for the } \\
\text { dissemination of information. } \\
\text { 10. Acquire knowledge, techniques and } \\
\text { methodologies for the design of tourist routes. }\end{array}$ & $\begin{array}{l}\text { 7. Capacity for analysis and synthesis. } \\
\text { 8. Oral and written communication in } \\
\text { native language. } \\
\text { 9. Organisational and planning capacity. } \\
\text { 10. Ability to manage information. } \\
\text { 11. Motivation for quality. } \\
\text { 12. Teamwork. }\end{array}$ \\
\hline
\end{tabular}

Source: UCM, 2019b. Own elaboration

Since this subject began to be taught during the 2012-13 academic year, it has had an average of forty students enrolled per year, a considerable number taking into consideration that it is an elective subject. These students represent a wide variety of backgrounds in terms of personal knowledge and also in terms of their nationalities. An important percentage of the students completing the degree in Spain are Asian 
and some others are part of international programs such as the ERASMUS. From the experience gained teaching this subject it is observed: (1) the students use technologies and social networks on a daily basis but do not know how to apply them to the professional field; (2) they often have limitations in the communication of their ideas and rely on visual aspects in detriment of the content; (3) some lack basic geographic and cartographic knowledge; (4) they find it difficult to relate and apply what they do with the real needs and tourist characteristics of the destination.

Therefore, taking into account the competencies of the Degree (ANECA, 2004), the learning objectives and general competencies for this subject are defined (Table 1).

To achieve all these objectives and competencies, the subject is divided in two. Half of the hours are theoretical sessions and the other half are dedicated to practices that consist essentially of the individualised analysis of cases through readings and videos and the completion of a route. This activity aims to achieve some of these general competencies of the subject, as well as a series of transversal competencies, indicated ut supra. And to this end, a complex methodology has been designed, set out within a student centred learning that defends the need for cooperation, following cooperative learning models so that students are able to create part of their knowledge and reason about it, following the process called metacognition and co-evaluation using rubrics (Kim \& Davies, 2014).

\section{Methodology}

\subsection{The process and resources used}

The geographic tools used for this project: GPS, geovisors and GIS Cloud, allow the gathering of data and the visualisation of the results, and permits also the acquiring of spatial skills and knowledge about basic geographic and tourist concepts (Table 2). They have specifically used the resources offered by the National Geographic Institute (the app "GPS Mapas de España" and the Iberpix geovisor) which are free, good quality and easy to handle. In addition to this, the GIS Cloud offered by Esri (ArcGIS Online and Story Map) has been used since it is free and it doesn't require a high level of computer savvy (Kerski, 2019) and also because it allows students to upload data, make maps and integrate them in an ordered format with accompanying text, photographs or graphics; likewise, the diversity of accessible templates for it makes available an extensive range of different options and layouts, such as timelines (Berendsen, et al., 2018).

Table 2. Didactic utility of the resources used

\begin{tabular}{|l|l|l|l|}
\hline \multicolumn{1}{|c|}{ Resource } & \multicolumn{1}{|c|}{ Organism } & \multicolumn{1}{|c|}{ Use } & \multicolumn{1}{c|}{ Competencies/ skills } \\
\hline $\begin{array}{l}\text { App "Mapas de España" } \\
\text { (Spain maps) }\end{array}$ & $\begin{array}{l}\text { Instituto Geográfico } \\
\text { Nacional (IGN) }\end{array}$ & $\begin{array}{l}\text { Collecting points of the route } \\
\text { Nacional (IGN) }\end{array}$ & $\begin{array}{l}\text { Spatial competencies } \\
\text { Digital competencies }\end{array}$ \\
\hline Iberpix 4 & Esri & $\begin{array}{l}\text { Collecting coordinates of the } \\
\text { different resources }\end{array}$ & $\begin{array}{l}\text { Spatial competencies } \\
\text { Digital competencies } \\
\text { Teamwork }\end{array}$ \\
\hline ArcMap 10.8 & Esri & $\begin{array}{l}\text { Converting coordinates taken } \\
\text { into SHP }\end{array}$ & Spatial competencies \\
\hline Freld work & $\begin{array}{l}\text { Recognising the territory } \\
\text { Collecting points of the route } \\
\text { tracking) } \\
\text { Taking photographs }\end{array}$ & $\begin{array}{l}\text { Spatial competencies } \\
\text { Capacity for planning and organising } \\
\text { Teamwork }\end{array}$ \\
\hline Flickr Online & $\begin{array}{l}\text { Visualisation of resources and } \\
\text { routes }\end{array}$ & $\begin{array}{l}\text { Spatial competencies } \\
\text { Atoring photographs }\end{array}$ & $\begin{array}{l}\text { Creativity } \\
\text { Teamwork }\end{array}$ \\
\hline ArcGIS Story Map & Esri & $\begin{array}{l}\text { Presentation of the } \\
\text { collaborative map } \\
\text { Individual presentation of each } \\
\text { route }\end{array}$ & $\begin{array}{l}\text { Spatial competencies } \\
\text { Creativity } \\
\text { Digital competencies } \\
\text { Capacity for planning and organising } \\
\text { Teamwork } \\
\text { Narrative }\end{array}$ \\
\hline
\end{tabular}

Own elaboration 
The creation of the route begins with the choice of the theme, which has to take into consideration the city's resources and, in addition to being innovative and attractive, it must adapt to a strategy that involves selecting which part of the city wants to be shown. Therefore, the students have to learn about the tourist situation in the city and try to promote decongestion through their route by showing non-tourist neighbourhoods or, on the other hand, offering new products in the most visited areas. Once the theme has been chosen, they must carry out an inventory of the elements that they will include as resources and as complementary services to the route, justifying in both cases their choices. With all this information they begin the construction of the narrative so characteristic of the GSM.

Parallel to this process, during the time assigned to practical classes, the teacher will explain the basic concepts of geography during three two-hour workshops. These concepts include coordinates, projection systems, etc. and cartography (typologies, colours, map elements ...) to teach the use and the helpfulness of the GPS and the geovisors. During the first session, after the theoretical explanation and the installation of the "Spain in Maps" app, the students take a tour around the university and when they finish they visualise it in Iberpix 4. With this viewer they also learn to modify the track and draw new ones.

Before holding the second session, students should have received conceptual information on routes and itineraries, through theoretical classes. The teacher must explain during those lectures the basic features of the routes, their characteristics and the main causes of success and failure, exemplifying with different real products. Additionally, they must have thoroughly addressed the situation of current urban destinations and the role that tourism products have in them, in line with different models and policies. In this second session, students learn to take the location coordinates of each of the elements that they are going to include in their route and create an inventory with the basic information of each one. Therefore, with the help of the teacher, who has to manage the ArcMap 10.8, the coordinates are adapted to be viewed in ArcGIS Online. These steps have been completed with an explanation of what geographic information systems (GIS) are and an introduction to the concept of a Story Map.

For the third session, the students must have their inventories ready and have independently carried out their own field work. They must have recorded the track of their route (identified the point of origin and destination, as well as the order in which the resources are going to be shown), identified the space in which they are going to intervene and have taken photographs. They have to create an album on Flickr with those images that they can complete with photographs obtained from creative commons platforms. In this session, the students, with the help of the teacher, review each of the routes (tracks and points) in the ArcGIS Online viewer and start the viewing process with a web application.

\subsection{Organisation of the Story Maps routes and the collaborative map}

Groups of between three or four people have been created to carry out all the necessary steps to design a route according to: the characteristics of the city; the existing routes offered in Madrid; the needs and problems of the city; the available resources and the current interests of the tourist demand. Madrid has been the chosen city to carry out this activity because: (1) it is known by the students since Complutense University of Madrid is located in this city; (2) it is a familiar and close by for everyone, which will make it easier for them to carry out the necessary field work; (3) it is a very important urban destination that offers the characteristics and problems that students tackle in different subjects; (4) it has a diverse heritage that favours the realisation of many and very different routes, which makes it possible to analyse the competition while posing a challenge.

The designed activity is part of the work methodology based on the students' collaboration. Part of the project is developed in the classroom under the tutelage of the teacher and another part is done individually, which has been especially useful since the students have had to finish their work at home during the confinement of the spring of 2020 due to the COVID-19 pandemic. This has given a special value to the result, at a time when virtual trips, without leaving the house, have become viral ${ }^{3}$. Therefore, this type of project serves as a working document for tourism professionals, since it allows to see in a reality the results of the design of the route, and it can also be adapted to work as visits from a person's home, adapting to the most restrictive and sustainable traveling philosophies known as staycation (Molz, 2009).

3101 Ways to Travel Without Leaving Your House https://www.cntraveler.com/story/l01-ways-to-travel-without-leaving-your-house (last consultation made on April 30, 2020) 
The students will begin their individual work and, with guidance of the teacher if needed, will create a story around the chosen elements and select which aspects (not descriptive) they want to tell in each case. In this way, they have to research each resource and select those aspects that are related to the theme of their route and that they consider may be interesting and attractive to the tourists. With all this information a narrative is built. For their final presentation, each group chooses the templates that best adapt to what they want to communicate; the most used being the "Story Map Tour" (Figure 1). They locate each of the resources on the map and link it to an image, a text and sometimes include links to external websites (with basic information to access the site or with additional information) and even videos that are related to the theme of the route.

Figure 1. Example of route presented with the "Story Map Tour" template

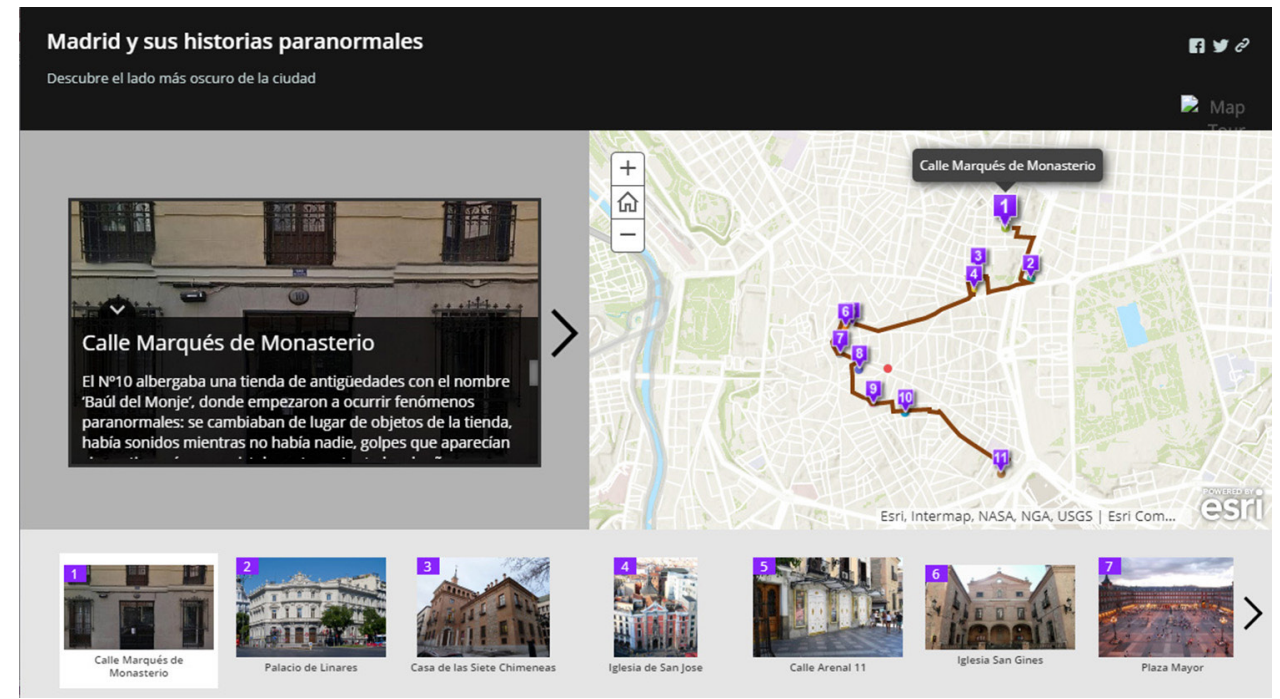

Source: Student' Story Map of the "Itineraries and tourist information" 2019-2020

Figure 2. Collaborative Story Map
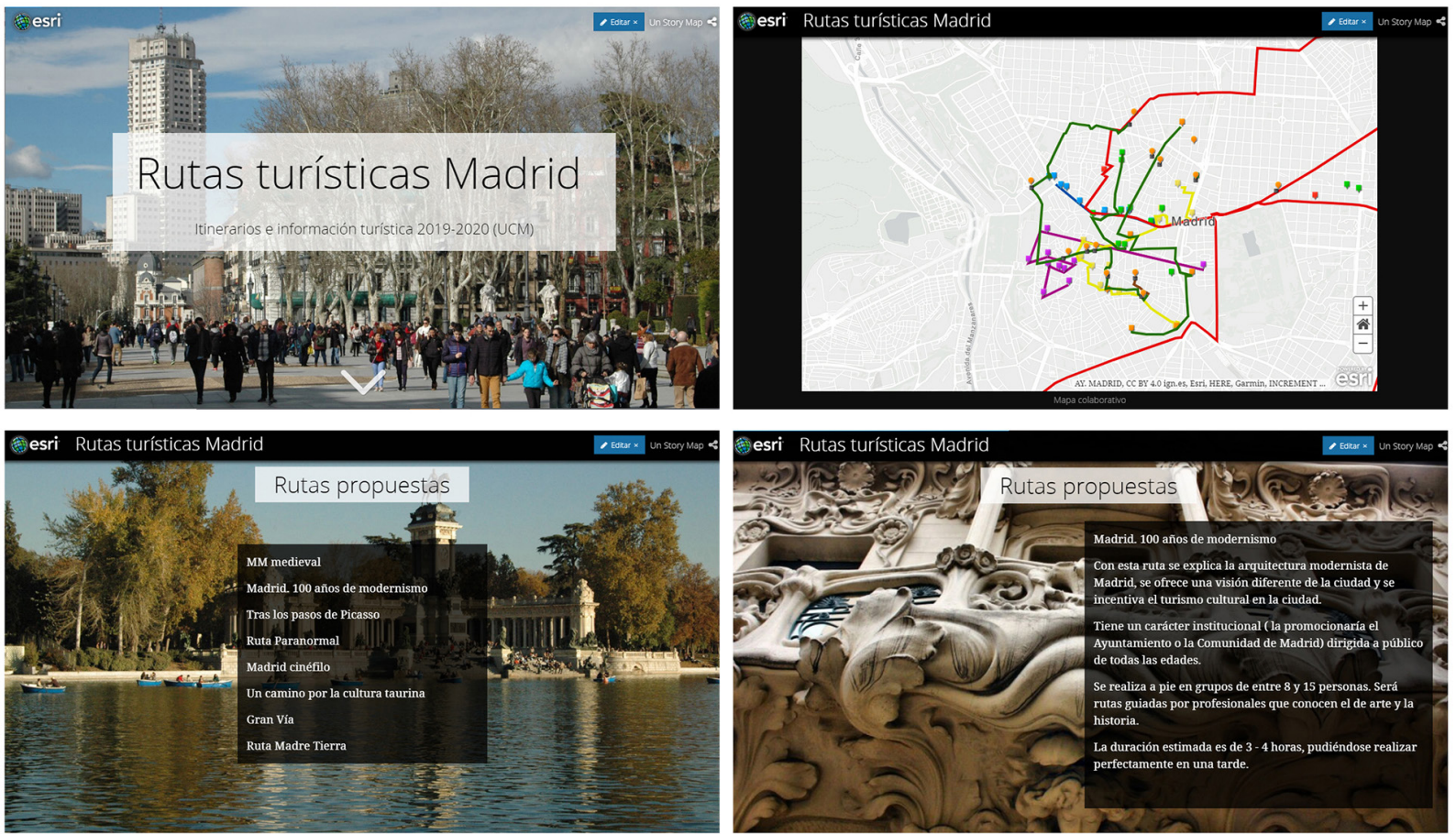

Own elaboration (https://arcg.is/lu5i59) 
After this work is done, the teacher will create a collaborative map with the eight routes prepared by the students and design a Story Map to present their projects (Figure 2). To do this, each group is asked to present, using Google Forms, the following aspects: (1) presentation of the route (topic, space ...); (2) justification of the chosen topic, space and resources; (3) objectives; (4) what does your route bring to the city and (5) basic aspects of the route: what will you see? What will be done during your tour? Who is the audience you are targeting? How many people per group? Who offers the service? How is it offered (guided, free ...)? How long does it last? How are the trips made? How much does it cost?

\subsection{Evaluating}

Once the students have presented their routes, the addresses of all of them are shared among the classmates who are going to co-evaluate them (Figure 3). To do this, an evaluation model based on a check list and rubrics have been previously developed. This checklist, which indicates whether or not it meets certain criteria, includes aspects considered essential in the creation of a successful route (Table 3), while the rubric gathers items related to didactic aspects and the presentation of work. Four options are included in the latter in order to keep students from always positioning themselves in the intermediate level (Table 4). With these it is intended that students develop an analytical and critical capacity and that they know how to identify in the work of their peers the elements that can enhance the success or failure of the route.

Table 3. List of items to check

\begin{tabular}{|l|l|l|}
\hline & Yes & No \\
\hline It has a well-defined thematic core & & \\
\hline The resources offered can be accessed & & \\
\hline It complements the city's tourist options & & \\
\hline Dimensions are adequate & & \\
\hline It is an innovative route & & \\
\hline It enhances the experience & & \\
\hline It is considered to be viable & & \\
\hline
\end{tabular}

Own elaboration

Table 4. Rubrics for evaluating routes submitted via GSM

\begin{tabular}{|l|l|l|l|l|}
\hline & $\mathbf{1}$ & $\mathbf{2}$ & $\mathbf{3}$ & $\mathbf{4}$ \\
\hline $\begin{array}{l}\text { Order and } \\
\text { presentation }\end{array}$ & $\begin{array}{l}\text { The project presents } \\
\text { an excessively } \\
\text { schematic level. }\end{array}$ & $\begin{array}{l}\text { The work is messy and } \\
\text { difficult to understand. }\end{array}$ & $\begin{array}{l}\text { The work is } \\
\text { presented correctly } \\
\text { in terms of order and } \\
\text { presentation. }\end{array}$ & $\begin{array}{l}\text { The work is well } \\
\text { presented, attractive } \\
\text { and it creates interest. }\end{array}$ \\
\hline Content & $\begin{array}{l}\text { It presents very little } \\
\text { information. }\end{array}$ & $\begin{array}{l}\text { It presents some } \\
\text { information but quite } \\
\text { a bit is missing. }\end{array}$ & $\begin{array}{l}\text { It contains most of the } \\
\text { relevant information. }\end{array}$ & $\begin{array}{l}\text { It contains all the } \\
\text { relevant information. }\end{array}$ \\
\hline Discussion & $\begin{array}{l}\text { The discussion has } \\
\text { little content. }\end{array}$ & $\begin{array}{l}\text { The information about } \\
\text { the resources used is } \\
\text { highly descriptive. }\end{array}$ & $\begin{array}{l}\text { Resource information } \\
\text { is interpretive. }\end{array}$ & $\begin{array}{l}\text { Resource information } \\
\text { is interpretive and } \\
\text { attractive. }\end{array}$ \\
\hline Images & $\begin{array}{l}\text { The presentation lacks } \\
\text { images. }\end{array}$ & $\begin{array}{l}\text { The images are } \\
\text { not related to the } \\
\text { discussion. }\end{array}$ & $\begin{array}{l}\text { Very stereotypical } \\
\text { images are chosen. }\end{array}$ & $\begin{array}{l}\text { Appropriate images } \\
\text { are chosen for the } \\
\text { discussion. }\end{array}$ \\
\hline Synthesis capacity & $\begin{array}{l}\text { It presents very little } \\
\text { information. }\end{array}$ & $\begin{array}{l}\text { It elaborates the } \\
\text { project in a manner } \\
\text { that can be considered } \\
\text { to be either too scarce } \\
\text { or too excessive. }\end{array}$ & $\begin{array}{l}\text { It correctly } \\
\text { summarises the } \\
\text { content. }\end{array}$ & $\begin{array}{l}\text { It summarises } \\
\text { correctly and uses } \\
\text { adequate vocabulary. }\end{array}$ \\
\hline
\end{tabular}

$1=$ Poor $2=$ Basic $3=$ Good $4=$ Excellent

Own elaboration 
Figure 3. Examples of the Story Maps made for different routes presented by the students
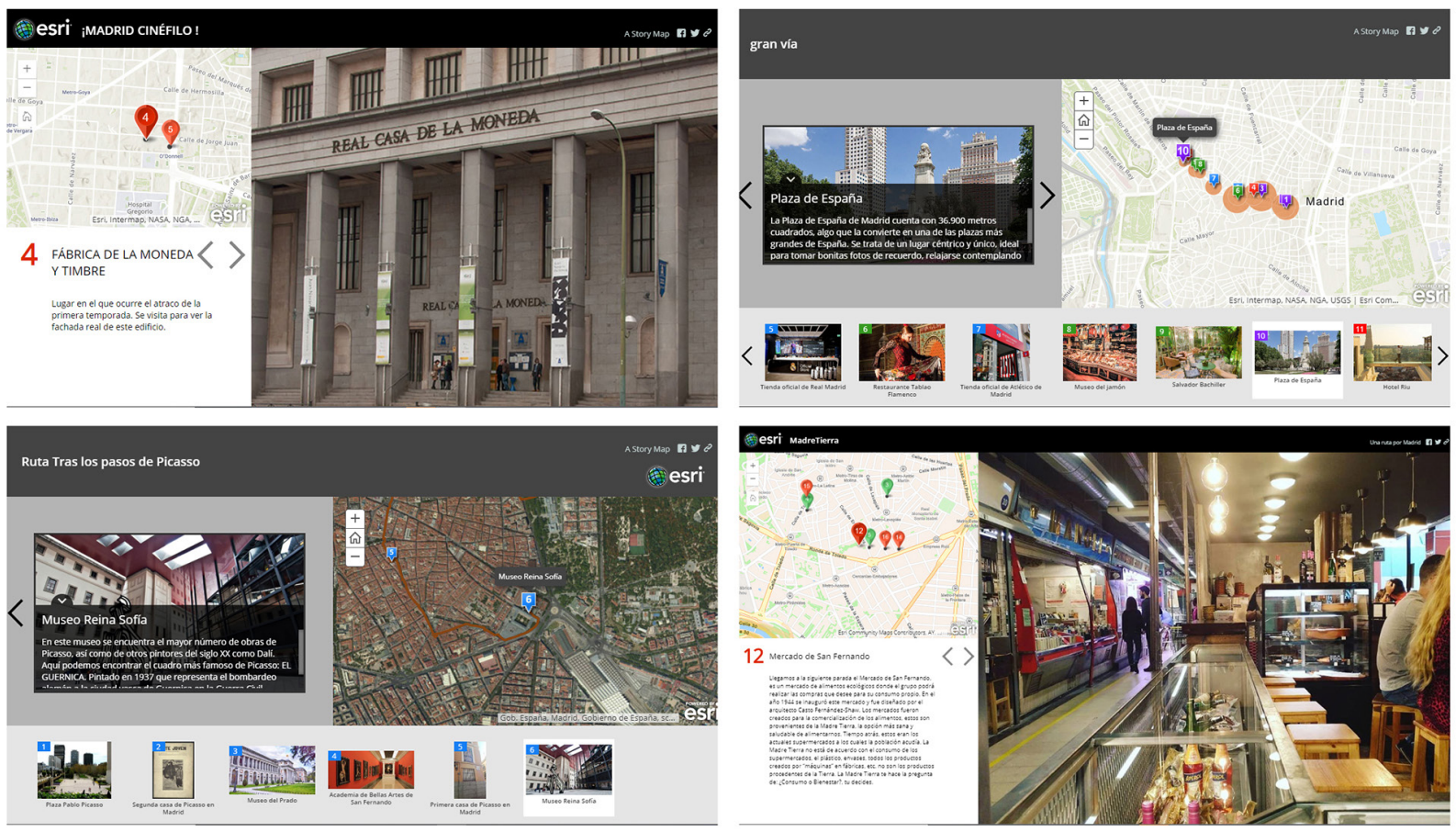

Source: Students' Story Map of the "Itineraries and tourist information" 2019-2020

\section{Results}

The results are organised into two blocks. To begin with, the technical part of the preparation of the GSM is analysed and then the students' participation, their perception of the activity and its validity. For this second part, a questionnaire was designed that the students have completed anonymously using google forms. Their responses and the observations of the process by the teacher carried out directly in the classroom and through the consultations made by the students, allow us to assess the activity in a multi-faceted way.

The students have completed an anonymous questionnaire, from which than literal answer have been cited. The results are presented qualitatively since the sample is small (40 people), which does not allow statistical analysis nor graphic representation.

\subsection{Preliminary assessment of design of the technical part of the preparation of the GSM}

The purpose of the preliminary evaluation of the Atlas History Map design is to identify which technical and didactic errors might have occurred that have impeded the fluid development of the activity or have altered its initial design (Table 5). During the sessions held in the classroom, there have been numerous technical problems that have arisen and that have been consequentially resolved. Most have been derived from the licenses of the programs used. There have also been conceptual problems related to what a route must be like and the characteristics that these must present.

They are presented in this case as a table so that this situation can be foreseen in case of reproducing the work methodology for similar subjects, which would be feasible.

Table 5. Issues identified during the GSM design process and methods used to resolve them

\begin{tabular}{|c|l|l|}
\hline Element & \multicolumn{1}{|c|}{ Issue Encountered } & \multicolumn{1}{c|}{ Method to Resolve the Issue } \\
\hline ArcGIS Online & $\begin{array}{l}\text { Free sample program licenses last only one } \\
\text { month, insufficient time to get the job done. }\end{array}$ & $\begin{array}{l}\text { During the COVID-19 crisis Esri offered a free license } \\
\text { that lasted the entire course. The students made use } \\
\text { of it. It would be convenient in the coming years for } \\
\text { everyone to use the license that the university has. } \\
\text { And, developer's licenses are available in Esri. }\end{array}$ \\
\hline
\end{tabular}




\begin{tabular}{|l|l|l|}
\hline GPS & $\begin{array}{l}\text { The free Maps of Spain App is not available } \\
\text { in the Apple Store. }\end{array}$ & $\begin{array}{l}\text { For students who have their phones with iOS operating } \\
\text { system, they have been offered the option of the Basic } \\
\text { Maps Spain App (IGN) }\end{array}$ \\
\hline Resources & $\begin{array}{l}\text { Students take the coordinates of the } \\
\text { resources with the help of Iberpix and once } \\
\text { the ZIP file is created, ArcGIS does not } \\
\text { recognise it. }\end{array}$ & $\begin{array}{l}\text { The coordinate system must be assigned with ArcMap } \\
\text { 10.8. The students do not manage the program so it is } \\
\text { the teacher who has to do this step and give the ZIP } \\
\text { files to each group. }\end{array}$ \\
\hline Photographs & $\begin{array}{l}\text { Students have not taken attractive or } \\
\text { representative photographs during their } \\
\text { field work and use images from the internet. }\end{array}$ & $\begin{array}{l}\text { Show them the existence of creative commons image } \\
\text { banks. } \\
\text { Raise their awareness about the importance of } \\
\text { respecting copyright. }\end{array}$ \\
\hline
\end{tabular}

Own elaboration

\subsection{Assessing Student Engagement with the GSM in a Learning Environment}

The results in this section are organised by the following research questions related to three main ideas. Are GSM a suitable tool? What kind of skills do they provide and what role do they play in their training as future professionals? And what is its usefulness as a teaching resource? For this, a questionnaire with nine differently formulated questions has been designed. There are three yes-or-no questions (in one of them the justification of the answer is requested); three more in which various options are offered and students have to position themselves with the phrases that best suit their impression and three other questions whose answers are left open for students to reflect on. There is also a space at the end of the questionnaire for them to freely expose their critical assessment. And, in regards to the content of the aforementioned questions, there are three related to each of the three main issues. Some of the questions explore the students' opinions on the future value of virtual routes as possible alternatives to real routes and as an element of interest in a possible change in the tourism model.

In respect to the question about the adequacy of GSM as the most appropriate tool to approach the creation of a tourist product, all the students respond that the work of preparing the route, almost autonomously, has allowed them to better understand the aspects explained by the teacher in the theory classes: the importance of the subject, the selection of resources and the collaboration between stakeholders. In addition to this, it has made them consider how to link the most visual aspects with the marketing of the product and some of them have even reflected on the fact that they have noticed differences between being a consumer of routes and being a designer of them. Likewise, all the students recognise that the work has allowed them to identify and individualise the stages involved in creating the route, its contents, and even putting it into operation, which would be the final presentation.

"This activity has helped me better understand the concepts in a real way." (student \#17)

"It has allowed us to do the entire process of preparing the route and analyse the problems that exist when creating a successful tourism product." (student \#20)

The most complicated phase for all students has been the planning and, within it, choosing the main theme. All of them highlighted in their responses the importance of the selection of resources in line with the chosen theme and among each other, since it has been a challenge to give coherence to the discourse and find the relationship between the selected elements. In addition, they have realised that there are many aspects to take into account and that they would need to check the viability of that product in a specific terrain, being aware of the characteristics of the city.

"The planning of the route has not been as easy as I thought it would be. It's difficult to organise the order of the stops and to have them make sense." (student \#5)

The students have also been presented with a list consisting of ten options and the request to choose among them the type of competencies this exercise has provided them with and what role they play in their training as future professionals. All of them are competencies to be acquired in the subject but only five correspond to those contemplated for this activity. All students agree on their answers: development of creativity, spatial competencies and knowledge of digital tools. Surprisingly, a little more than half consider that it has favoured teamwork and the ability to organise and plan, both being important competencies for the realisation of the project. Also half of the students have considered that the activity has developed their motivation for quality, a competence that had not been contemplated. Only a very small 
number of students have considered that the activity has enhanced their oral and written communication (narrative). In relation to this question, an open space has been left for them to add some more competencies and almost all the students have indicated that they have acquired geographic knowledge.

Three quarters of the students (75\%) consider that the tools used are innovative. Some of them had used geovisors before but the majority of the students had never worked with GPS, geovisors, GIS or GSM. All of them explain that these tools are important in their training as future tourism professionals, although some do not fully see their practical utility in the work market.

"We have used programs that seem very important to any tourist professional." (student \#6)

Regarding the practicality of GSM as a teaching resource, three quarters of the students consider that they are indeed very useful. To confirm their assessment, they were offered a list consisting of nine phrases from which they had to select those that best suited their impressions. These statements included, in an alternating way, from very positive evaluations such as "I have acquired knowledge and developed skills in a simple way" to other negative ones "I have not learned anything with this activity". The first of them has been chosen by half of the students, while the negative has not been selected by any. The students have felt more identified with the descriptive sentences of the activity that did not refer to the simplicity or difficulty of the activity and that more aseptically reflected their opinion. In order of more to less acceptance by students: "I have learned to design a route", "I had never used those tools before", "I found the activity interesting" (100\%); "In the Degree we have not had access to instruments like this that can be useful to our work", "The future of tourism lies in the use of Apps" (50\%), or "I have learned concepts and developed skills but not effectively" and "There are other better ways to learn" $(0 \%)$.

The last of the questions related to the usefulness of the activity has a different focus. It doesn't question what they have done but the usefulness of the final product itself, the route. Again, six phrases have been offered and students had to choose the one that most closely matches their perceptions. The options proposed include various aspects such as the value that virtual routes have traditionally had, such as marketing and management elements, or the role they may have in the future.

The phrase "It is useful for customers because it allows them to visualise what they are going to hire" is the one that has been selected by all students, followed by these two: "It is useful for professionals because it allows them to visualise the route, something that can't be otherwise tested before its realisation" and "It serves as a marketing strategy to publicise a destination". Half of the students consider that the virtual routes "Serve as a way to be a tourist from home (staycation)" or "Serve as a tool for planning, control and containment of the tourism", although the latter is essential and has been explained in the classroom, while a minority consider that "It serves for customers to make the journey autonomously".

Finally, the students have used the free space at the end of the questionnaire to leave their impressions of the activity, summarising in some of the comments what was pursued by the realisation of the aforementioned questionnaire:

"I think that the most useful aspect of this activity has been learning to diversify the city's tourism offer and the importance of promoting and developing the tourist products. It has also helped me develop my creativity. " (student \#16)

"Without a doubt, these are useful and innovative tools that show the routes in a very visual and modern way, although running the programs has had some difficulty for all of us." (student \#35)

"It has helped us bring out our most creative side by generating something new that can interest people. It can help us develop a professional opportunity that we hadn't thought of before and that it can definitely be interesting." (student \#8)

\section{Discussion}

One of the main differences between the traditional work that has been completed in previous years, consisting of creating a route without the use of geospatial technologies, and the one presented in this article is that these tools add extra value to the project. This value is given by understanding the space through cartography, which trains the student to think spatially (spatial concepts, spatial representation and spatial reasoning) and to see the spatial conditions of the route (traveling path, length, starting point and destination ...), by the development of the different phases of the work and also by the quality of the presentation. Its quality is not only due to its visual power but also to the homogenisation of the 
product in terms of the structure, an aspect that makes it easier for the teacher to compare the different works and for the students to be able to easily co-evaluate them. Also, the motivation and involvement of the students has been greater than with other types of projects, as it has been noticeable taking into consideration the questions asked to the teacher during the process and the improved quality of the final work. So it can be said that most of the students have reached the proposed competencies for this activity. This corroborates the statements made by many authors that indicate that this type of tool favours the generation of knowledge in Primary and Secondary Education and, in this case, they extend to the university education (Strachan \& Mitchell, 2014; Berendsen, et al., 2018).

In addition to the aforementioned improvements, another advantage produced by this methodology has been the fact that the students have carried out, almost in an unconscious manner, the important chore of selecting the information that they will finally communicate. Therefore, unlike what would have happened with traditional presentation programs, they have had to choose a single image per element and a very specific text that must synthesise in less than ten lines what the students want to tell about that element within the tourist visit. They had to employ special care on communication style and orthography, of course. This has helped them understand the value of the image and the cartography, as essential elements in the communication process and how a text must be selected and constructed so that the document does not lose the reader's interest (Kosara \& Mackinlay, 2013).

They have also been asked to write a paper, of about 30 pages of extension, explaining the development of the work. This has been considered an important task since traditional work is essential when reflecting on the design and marketing of the routes and on the space and theme chosen. The use of geospatial technologies reinforces the acquisition of competencies such as creativity or teamwork and especially adds the development of spatial competencies (spatial perception, that is: location and orientation; ability to make and interpret maps, etc.), which is otherwise very difficult for students of the tourism degree to obtain. In addition to this, it creates a model that reduces the intangibility of the product and that favours the identification of design errors before being commercialised.

Indeed, restricting the routes to a common space that everyone knows first-hand, has allowed them to reconsider the role that their route would have in the tourism strategy of the city of Madrid. All the proposed routes are located, totally or partially, in Madrid's central district, the most touristic and saturated area in the city; although it is true that with some exceptions, most students have highlighted lesser-known neighbourhoods and spaces and have provided a complementary vision to the traditional one, directing the tourist's gaze towards little-known elements.

From the cases presented by the students, it can be perceived how the routes are still closely linked to cultural tourism and almost all of them highlight that aspect as a plot line (architecture, chronological eras, historical figures, etc.). It's worth mentioning the less common, but just as interesting, routes based on a participatory and therefore experiential nature, which is an essential part of today's tourism and can also be used as a tool for improving tourists' awareness on different topics and values, such as was previously explained in class. It can be appreciated through the choice of the subject and the space, as well as the justification and the business or institutional approach that they give to their routes, how they have learned the concepts and explanations presented in a theoretical way in the classroom by the teacher.

The students have been able to generate important feedback thanks to their teamwork and this has helped them develop a collaborative learning model, since each member has shared their knowledge and skills with their colleagues while they have debated to define the characteristics and objectives of their routes. For this, they have had the support of documentation provided by the teacher, which includes experiences that reflect the most common errors and the keys to the success of the routes, and they have had to debate and choose the options that they have finally presented.

The co-evaluation process deserves special mention. Their results have not been presented in the previous section because it is considered that it was not appropriate to make a detailed assessment of each of the projects presented. However, it should be noted that all students have participated in this activity with the correct criteria. In other words, they have not opted to assign the best grades to their classmates, but have scored according to their impressions, which are consistent with each other and coincide with those of the teacher. Also, some of the most striking projects from the visual point of view were not in terms of content and the students have known how to differentiate both aspects, without being carried away by the images presented. 
This methodology, consisting in the realisation of a track, the choice of elements, the presentation of the results through a GSM and the co-evaluation by the students who work independently, can be perfectly extrapolated to other subjects which contemplate the tourist and cultural itineraries. Although free tools provided by Esri with the developer license have been used for its development, the essence of this work can be also kept and developed with other resources such as StoryMap Knightlab or Google Tour Builder.

It also serves to inspire urban wanderings, with different objectives such as identifying tourist elements, aspects related to urban policies or reporting situations or actions considered problematic. These types of activities are increasingly frequent in teaching the Bachelor's and Master's degrees in Tourism and Geography.

The adaptation of this methodology to other subjects would imply an exhaustive previous theoretical reflection on the part of the teacher, something that needs to be done together with the preparation work that has to be finished before introducing the activity in the classroom. As we have seen in section 4.1 , several problems can arise. All of them are easily resolvable but require prior and annual testing and review, since the websites and apps used change their interfaces as well as their use conditions frequently. Also, certain imbalances might arise according to the different knowledge level and involvement of the students. To avoid this, a more directed model can be chosen in which each activity is much more guided and controlled through forms indicating which elements should not be missed in the work and have to be carried out as specified, so that by following those guidelines the work reaches the minimum levels of knowledge to pass the class.

Although the assessment of the activity by both students and teachers has been positive, it is surprising to see how many participants value geospatial technologies as a learning tool but not so much as tools for their professional future and how many don't believe that virtual routes could be part of the future of tourism and therefore, of their future as professionals. This belief might be caused by their own life experiences and the fact that they are yet to start working as tourism professionals. This is especially striking at the specific time when the work has been carried out, characterised by the confinement caused by the COVID-19 quarantine and an intense debate on the immediate future of tourism. This important debate involves proposing a new tourism model more sustainable and respectful with the environment and less invasive (Hof \& Blázquez-Salom, 2015). This shows that students are still very attached to the knowledge and discourse acquired so far in the traditional teaching classroom, among which there has not been any concern for seeking alternatives or improving their entrepreneurial abilities, which are basic in the professional development and promote resilience. The latter represents a new and great challenge for teachers of the Degree of Tourism which aims to train highly qualified professionals to work in a sector that, as mentioned at the beginning of this article, is subject to constant changes and is demonstrating to be very vulnerable.

\section{Conclusions}

The objective of this study was to demonstrate that the use of a teaching methodology based on the use of GSM improves student performance and enables them to acquire skills that will be key in their professional future. In addition to this, it allows to preview the tourist product and be able to recognise its errors and risks before making it public.

After the test carried out during the 2019-2020 academic year, it has been observed that the students have improved their performance when compared to previous years and this methodology allows the acquisition of important skills in their training. Likewise, from the results of the survey and from the experience in the classroom it can be affirmed that the students are aware of this change and feel more involved in their own learning process (What do they do? Why? And, for what?).

This methodology clearly presents an interactive work opportunity that is more attractive to the participants. This does not mean that this methodology should replace the previous ones, but both should be combined since it has been observed that both the theoretical classes and the elaboration, in conjunction, of a more detailed project are essential. This reduces the risk of students getting caught up on the more technical, aesthetic and visual aspects.

This experience shows that it is positive, even necessary, to introduce geospatial technologies in teaching as well as any other technique that allows us to modernise and speed up the teaching process. 
Despite the fact that the implementation of this type of techniques is not easy and requires significant preparation by the teacher and constant monitoring, the results are positive/good and can be applied to different places, and also to different subjects from different degrees, not just tourism. Because the tourism degree is still in its developmental stages, it is especially in need of educational advances, but the principles and techniques of teaching applied in other social sciences can be of use here, always taking into account the characteristics of the tourism sector.

\section{Funding}

This research was funded by the Spanish Ministry of Economy and Competitiveness (MINECO) Transformations of the historic urban landscape induced by tourism: contradictions and controversies, government and local governance (CSO2016-75470-R).

\section{Acknowledgments}

Special thanks to the students of the "Itineraries and tourist information" class of the Degree on Tourism at Complutense University of Madrid, during the 2019-2020 academic year.

\section{References}

ANECA (2004). Informe de la Comisión de Evaluación del diseño del Título de Grado de Turismo. Madrid: ANECA.

Arnandis-i-Agramunt, R. (2019). ¿Qué es un recurso turístico? Un análisis Delphi a la Academia Hispana. Cuadernos de Turismo, 43, 39-68. https://doi.org/10.6018/turismo.43.02

Benur, A. M., \& Bramwell, B. (2015). Tourism product development and product diversification in destinations. Tourism management, 50, 213-224. https://doi.org/10.1016/j.tourman.2015.02.005

Berendsen, M. E., Hamerlinck, J. D., \& Webster, G. R. (2018). Digital story mapping to advance educational atlas design and enable student engagement. ISPRS International Journal of Geo-Information, 7(3), 125. https://doi.org/10.3390/ijgi7030125

Blanco-Romero, A., Blázquez-Salom, M., De la Calle, M., García, M., Fernández-Tabales, A., Lois, R. C., Mínguez, M.C., Navalón-García, R., Navarro, E., \& Trotiño, L. (in press). Diccionario de turismo. Madrid: Ed. Cátedra.

Buhalis, D. (2000). Marketing the competitive destination of the future. Tourism management, 21(1), 97-116. https://doi.org/10.1016/S0261-5177(99)00095-3

Buzo, I., De Lázaro, M. L., \& Mínguez, M. C. (2014). Learning and teaching with Geospatial Technologies in Spain. In R. De Miguel Gonzalez \& K. Donert, K. (Eds.). Innovative learning geography in Europe: new challenges for the 21st century (pp. 77-86). Cambridge: Cambridge Scholars Publishing.

Calle, M. de la, Ferreiro, E., \& Mendoza, S. (2018). Concentración y desconcentración de la actividad turística sobre el espacio urbano. Reflexiones en torno a Madrid. Polígonos: Revista de geografía, 30, 143-170. http://dx.doi.org/10.18002/pol.v0i30.5690

Cárdenas-García, P. J., Pulido-Fernández, J. I., \& Carrillo-Hidalgo, I. (2016). Adquisición de competencias en el Grado de Turismo mediante el aprendizaje basado en estudios de caso. Aula Abierta, 44(1), 15-22. https://doi.org/10.1016/j.aula.2015.05.002

Chen, R. J. (2007). Geographic information systems (GIS) applications in retail tourism and teaching curriculum. Journal of Retailing and Consumer Services, 14(4), 289-295. https://doi.org/10.1016/j. jretconser.2006.07.004

Dangermond, J. (2016). Mapping the story of government transparency. Governing. Retrieved from www. governing.com/cityaccelerator/blog/mapping-the-story-of-government-transparency.html.

De Lázaro, M. L., De Miguel, R., \& Morales, F. J. (2017). WebGIS and Geospatial Technologies for Landscape Education on Personalized Learning Contexts. ISPRS Int. J. Geo-Inf., 6, 350. https://doi. org/10.3390/ijgi6110350 
De Lázaro, M. L., Borderías, P., \& Morales, F. J. (2020). Citizen and Educational Initiatives to Support Sustainable Development Goal 6: Clean Water and Sanitation for All. Sustainability, 12(5), 2073. https://doi.org/10.3390/su12052073

De Miguel, R., Buzo, I., \& De Lázaro, M. L. (2016). New challenges for geographical education y researching: The Digital School Atlas. In Crisis, Globalization and Social and Regional Imbalances in Spain; Spanish Contribution to 33rd IGU Congress Beijing (pp. 187-197). Madrid: Comité Español de la UGI. Retrieved from https://www.age-geografia.es/site/wp-content/uploads/2016/07/crisis_ globlalization_UGI_eng_2016_WEB.pdf

De Miguel, R., \& De Lázaro, M.L. (2020). WebGIS Implementation and Effectiveness in Secondary Education Using the Digital. Atlas for Schools. Journal of Geography, 119(2), 74-85. https://doi.org/1 $\underline{0.1080 / 00221341.2020 .1726991}$

Dickinson, S., \& Telford, A. (2020). The visualities of digital story mapping: teaching the 'messiness' of qualitative methods through story mapping technologies. Journal of Geography in Higher Education, 1-17. https://doi.org/10.1080/03098265.2020.1712686

Esri (2012). Telling Stories with Maps- White Paper. Retrieved from https://cpb-us-el.wpmucdn.com/ blogs.cornell.edu/dist/a/3337/files/2013/12/Telling-Stories-with-Maps-White-Paper-1-1c239jb.pdf

García, J. V., \& Pérez, M. C. (2008). El grado en turismo: un análisis de las competencias profesionales. Cuadernos de Turismo, 21, 67-83. Retrieved from https://revistas.um.es/turismo/article/ view/24991/24281

Gavalas, D., \& Kenteris, M. (2011). A web-based pervasive recommendation system for mobile tourist guides. Personal and Ubiquitous Computing, 15(7), 759-770. Retrieved from https://link.springer.com/ article/10.1007/s00779-011-0389-x

González, M.J., \& De Lázaro, M.L. (2011). La geoinformación y su importancia para las tecnologías de la información geográfica. Ar@cne. Revista electrónica de recursos en Internet sobre Geografía y Ciencias Sociales, 148. Retrieved from http://www.ub.edu/geocrit/aracne/aracne-148.htm

Hof, A., \& Blázquez-Salom, M. (2015). Changing tourism patterns, capital accumulation, and urban water consumption in Mallorca, Spain: a sustainability fix? Journal of Sustainable Tourism, 23(5), 770-796. https://doi.org/10.1080/09669582.2014.991397

Ilies, G., \& Ilies, M. (2018). A Storytelling Map of the Upper Mara Valley. Cartography E Geoinformation, $17(30), 16-27$. https://doi.org/10.32909/kg.17.30.2

Kerski, J. J. (2019). Types of Story Maps. In S.L. Arlinghaus, J.J. Kerski, A. Evans \& M. Naud (Eds), Spatial Thinking in Environmental Contexts: Maps, Archives and Timelines, 3 (pp. 155-172). https://doi. org/10.1201/b22099-22

Kim, A. K., \& Davies, J. (2014). A teacher's perspective on student centred learning: Towards the development of best practice in an undergraduate tourism course. Journal of Hospitality, Leisure, Sport E Tourism Education, 14, 6-14. https://doi.org/10.1016/j.jhlste.2013.12.001

Kolb, D. A., Boyatzis, R. E., \& Mainemelis, C. (2001). Experiential learning theory: Previous research and new directions. In R. J. Sternberg \& L. F. Zhang (Eds), Perspectives on thinking, learning, and cognitive styles, 1(8), (pp. 227-247). https://doi.org/10.4324/9781410605986-9

Kosara, R., \& Mackinlay, J. (2013). Storytelling: The Next Step for Visualization. Computer, 46, 44-50. https://doi.org/10.1109/MC.2013.36

López G, T.J., Lara, F., \& Merinero, R. (2006). Las rutas turísticas como motor de desarrollo local. El caso de la Ruta de "El Tempranillo". Estudios Turísticos, 137, 131-145.

Marta, M., \& Osso, P. (2015). Story Maps at school: teaching and learning stories with maps. J-ReadingJournal of Research and Didactics in Geography, 2. Retrieved from http://www.j-reading.org/index.php/ geography/article/view/116

Martínez-Hernández, C. (2014). El uso de SIG de software libre para la consolidación de contenidos de la geografía física de España en $2^{\circ}$ de Bachillerato. II Congreso Internacional de Innovación Docente (pp. 1046-1055). Murcia: Universidad de Murcia y Campus Mare Nostrum. 
Martínez-Hernández, C., Ibarra, A., Pérez, J., \& Figueres, C. (2016). El uso de SIG de software libre en una práctica de Biología y Geología de $4^{\circ}$ de ESO: los ecosistemas. Didáctica de las Ciencias Experimentales y Sociales, 30, 103-116. https://doi.org/10.7203/dces.30.4584

Martínez-Hernández, C., \& Yubero, C. (2020). Explaining Urban Sustainability to Teachers in Training through a Geographical Analysis of Tourism Gentrification in Europe. Sustainability, 12(1), 67. https:// doi.org/10.3390/su12010067

Michel, E., \& Hof, A. (2013). Promoting Spatial Thinking and Learning with Mobile Field Trips and eGeoRiddles. In T. Jekel, A. Car, J. Strobl, Griesebner, G. (Eds), GI_Forum 2013: Creating the GISociety, (pp. 378-387). Wichmann Verlag Berlin. https://doi.org/10.1553/giscience2013s378

Milano, C. (2018). Overtourism, malestar social y turismofobia. Un debate controvertido. Pasos. Revista de Turismo y Patrimonio Cultural, 16(3), 551-564. https://doi.org/10.25145/j.pasos.2018.16.041

Molz, J. G. (2009). Representing pace in tourism mobilities: Staycations, slow travel and the amazing race. Journal of Tourism and Cultural Change, 7(4), 270-286. https://doi.org/10.1080/14766820903464242

Mossberg, L. (2007). A marketing approach to the tourist experience. Scandinavian journal of hospitality and tourism, 7(1), 59-74. https://doi.org/10.1080/15022250701231915

Navalón-García, R. (2014). Diseño y gestión de rutas culturales: de la teoría a la práctica. In L. Rubio \& G. Ponce (Eds.), Escenarios, imaginarios y gestión del patrimonio (pp. 207-217). México: Ed. Servicio de Publicaciones de la Universidad Autónoma Metropolitana de Xochimilco y Universidad de Alicante.

Nguyen, T., Edwards, S., Rahall, N. J., Scott, M., \& Cragle, J. (2016). GIS Story Maps: A Tool to Empower and Engage Stakeholders in Planning Sustainable Places. Final report. University of Delaware: Delaware. Retrieved from http://udspace.udel.edu/bitstream/handle/19716/21597/gis-story-maps-2016. pdf? sequence $=1$ \&isAllowed $=y$

Patterson, T. C. (2007). Google Earth as a (not just) geography education tool. Journal of Geography, 106(4), 145-152. https://doi.org/10.1080/00221340701678032

Portillo, H. L., Merino García, J., \& García-Rodríguez, M. (2017). Ruta cultural y didáctica por Valdemorillo (Madrid). Tecnología y desarrollo, 15, 3-35. Retrieved from https://revistas.uax.es/index.php/tec_des/ article/view/1180/968

Pulido, J. I. (2006). Por qué no funcionan turísticamente algunas rutas o itinerarios culturales. PH Boletín del IAPH, 60, 119-113. https://doi.org/10.33349/2006.60.2262

Rodríguez, J. M., Rubio, L., Esteban, C., \& Alonso, M. (2009). La importancia del aprendizaje y la adquisición de competencias en el sector turismo. Instituto de Estudios Turísticos, 179, 41-66. Retrieved from https://pdfs.semanticscholar.org/1209/1f158a9d32cffb0ead25b35b5a2ef0030efc.pdf

Schott, C., \& Sutherland, K. A. (2009). Engaging tourism students through multimedia teaching and active learning. Journal of teaching in travel \& tourism, 8(4), 351-371. https://doi. org/10.1080/15313220903047987

Sheldon, P., Fesenmaier, D., Woeber, K., Cooper, C., \& Antonioli, M. (2008). Tourism education futures, 2010-2030: Building the capacity to lead. Journal of Teaching in Travel E Tourism, 7(3), 61-68. https:// doi.org/10.1080/15313220801909445

Shor, I. (2012). Empowering education: Critical teaching for social change. Chicago \& London: University of Chicago Press.

Smith, S. L. (1994). The tourism product. Annals of tourism research, 21(3), 582-595. https://doi. org/10.1016/0160-7383(94)90121-X

Stankov, U., Durdev, B., Markovic, V., \& Arsenovic, D. (2012). Understanding the importance of GIS among students of tourism management. Geographia Technica, 2, 68-74.

Strachan, C., \& Mitchell, J. (2014). Teachers' perceptions of Esri Story Maps as effective teaching tools. Review of International Geographical Education Online, 4(3), 195-220. Retrieved from https://dergipark. org.tr/en/download/article-file/591037

Stoltman J.P., \& Lidstone, J. (2017). The End of the Beginning: the emerging role of International Research in Geographical and Environmental Education (IRGEE). International Research in Geographical and Environmental Education, 26(2), 87-90. https://doi.org/10.1080/10382046.2017.1295580 
Torres, E. (2006). Rutas culturales. Recurso, destino y producto turístico. PH Boletin del Instituto Andaluz del Patrimonio Histórico, 60, 84-97. https://doi.org/10.33349/2006.60.2259

Tussyadiah, I. P., Wang, D., \& Jia, C. H. (2017). Virtual reality and attitudes toward tourism destinations. In R. Schegg \& B. Stangl (Eds), Information and communication technologies in tourism 2017. Proceedings of the international conference in Rome, Italy, January 24-26, 2017 (pp. 229-239). https:// doi.org/10.1007/978-3-319-51168-9_17

UCM (2019a). Guía del Grado de Turismo del curso 2019/2020. Retrieved from https://comercioyturismo. ucm.es/estudios/grado-turismo-estudios-estructura

UCM (2019b). Guía Docente de "Itinerarios e información turística", curso 2019/2020. Retrieved from https://comercioyturismo.ucm.es/estudios/grado-turismo-plan-800015

Veugelers, W. (2000). Different ways of teaching values. Educational review, 52(1), 37-46. https://doi. org/10.1080/00131910097397 